\title{
21. FACIES, COMPOSITION, AND TEXTURE OF MISSISSIPPI FAN SEDIMENTS, DEEP SEA DRILLING PROJECT LEG 96, GULF OF MEXICO' ${ }^{1}$
}

\author{
Dorrik A. V. Stow, Michel Cremer, Laurence Droz, Audrey W. Meyer, William R. Normark, Suzanne O'Connell, \\ Kevin T. Pickering, Charles E. Stelting, S. A. Angell, and C. Chaplin ${ }^{2}$
}

\begin{abstract}
Eight lithologic facies recognized in the Mississippi Fan sediments drilled during DSDP Leg 96 are defined on the basis of lithology, sedimentary structures, composition, and texture. Of these, the calcareous biogenic sediments are of minor importance, volumetrically, as compared with the dominant resedimented terrigenous facies. Clay, mud, and silt are the most abundant sediments at all the sites drilled, with some sand and gravel in the midfan channel fill and an abundance of sand on the lower fan. Facies distribution and vertical sequences reflect the importance of sediment type and supply in controlling fan development. Sea-level changes and diapiric activity have also played an important role. Clay and sand fraction mineralogy closely mirror the dominant sediment source, namely, the Mississippi River system and adjacent continental shelf. Local and regional variation in composition on the fan mostly reflects facies differences.
\end{abstract}

\section{INTRODUCTION}

This chapter documents the lithologic facies recovered at nine of the Mississippi Fan sites during DSDP Leg 96 (Fig. 1) and summarizes the principal results of our various sedimentological analyses. Other related results are reported in more detail elsewhere in the volume (Pickering and Stow, this volume; Coleman, Bouma, et al., this volume; Cremer and Stow, this volume). Many of these data have also been reported by Stow et al. (1985).

Holes at the nine fan sites were drilled to depths of between about 200 and $600 \mathrm{~m}$ sub-bottom (see site chapters, this volume). At four of these sites $(617,620,621$, and 622 ), holes were drilled in the actively aggrading middle fan area at water depths between about 2450 and $2600 \mathrm{~m}$. This area is characterized by a sinuous channellevee complex with adjacent overbank deposits. The channel is $1.5-2.5 \mathrm{~km}$ wide and $40-45 \mathrm{~m}$ deep in the vicinity of the drill sites. Site 621 is located in the present channel thalweg on the outside of a meander bend, Site 622 is on the inside ("point bar") of a meander bend, Site 617 is on the back side of the western levee immediately adjacent to the channel near Site 621 , and Site 620 is located in overbank deposits outside the channel-levee complex approximately $18 \mathrm{~km}$ east of the channel axis. One other site (Site 616) was drilled in the middle fan area, about $55 \mathrm{~km}$ east of the channel axis. Site 616 was drilled through a 100-m-thick slump zone into the un-

\footnotetext{
${ }^{1}$ Bouma, A. H., Coleman, J. M., Meyer, A. W., et al., Init. Repts. DSDP, 96: Washington (U.S. Govt. Printing Office).

Addresses: (Stow) Geology Department, Nottingham University, Nottingham, United Kingdom; (Cremer) Départment de Géologie et Océanographie, Université de Bordeaux, Bordeaux, France; (Droz) Laboratoire Géodynamique Sous-Marine, Université Pierre et Marie Curie, Villefranche-sur-Mer, France; (Normark) U.S. Geological Survey, Menlo Park, CA 94025; (O'Connell) Ocean Drilling Program, 500 University Drive West, Texas A\&M University, College Station, TX 77843; (Pickering) Department of Geology, University of LniverLeicester LE1 7RH, United Kingdom; (Stelting) Chevron Oil Field Research Company, P.O. 36506. Hous, TX 77236; (Me (Stelting) Chevron On Box 36506, Houston, TX 77236; (Meyer) Ocean Drilling Program, Texas A \& M University, College Station, TX 77843; (Angell, Chaplin) Geology Department, Edinburgh University, Edinburgh, Scotland.
}

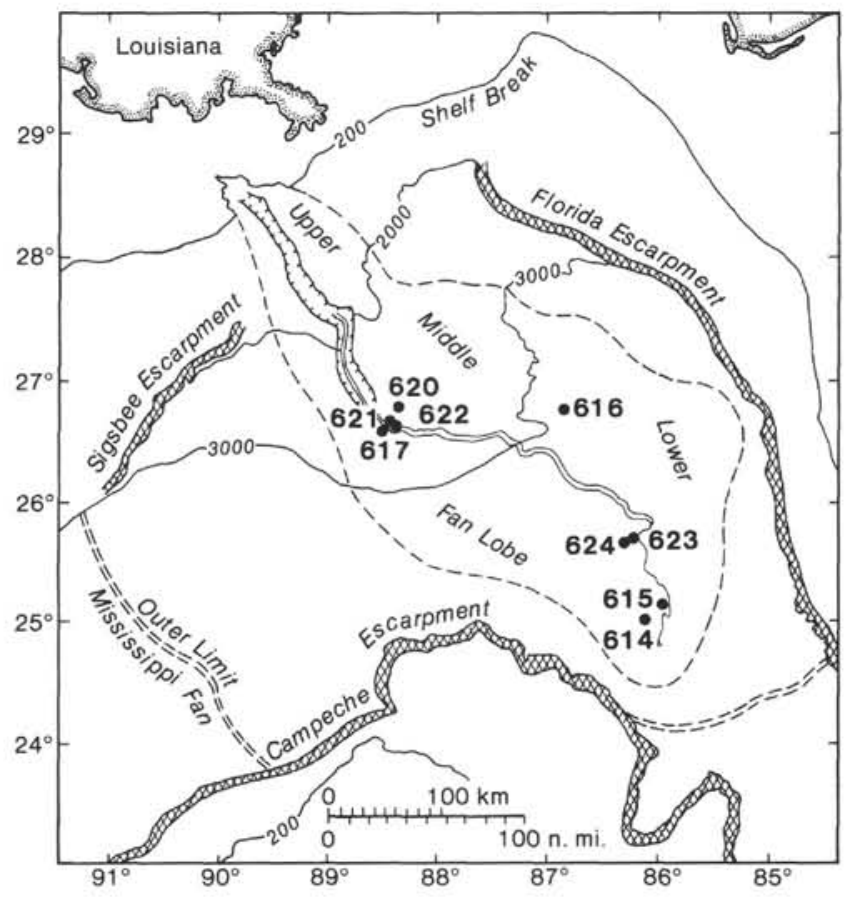

Figure 1. Location map for the Mississippi Fan DSDP Leg 96 sites.

derlying channel overbank deposits. However, these overbank deposits probably predate those of the most recent depositional fan unit penetrated at the other sites (see site chapters, this volume).

We drilled at four sites $(614,615,623$, and 624$)$ in the channel terminus/channel switching region of the fan at water depths between about 3180 and $3300 \mathrm{~m}$. These are referred to as lower fan sites in this volume, although one of the authors of this chapter (W. R. Normark) prefers to include the area of these drill sites in the lower part of the middle fan (Normark et al., this volume). Site 624 is located immediately adjacent to the most recently active channel, which is some $5-10 \mathrm{~m}$ deep at this point, Site 623 is about $5 \mathrm{~km}$ further to the northeast, 
and Sites 615 and 614 are $35-40 \mathrm{~km}$ downfan, in an area of very minor channel terminations and bifurcations.

All holes were cored continuously, but many holes had "washed" intervals at the base of each core. Core recovery was best in the upper 80 to $100 \mathrm{~m}$ although, in most cases, a good suite of wireline logs enabled us to interpret facies types in the deeper parts of wells where core recovery was poorer (Coleman, Constans, et al., this volume).

\section{METHODS}

Standard analytical techniques were used for this study, as described in, for example, Carver (1971) and Bouma (1969). As far as possible, the grain size, mineralogical, and chemical analyses were performed on subsamples of the same sample. Grain size analyses were completed by the sieve and pipette methods of dry sieving the $>63-\mu \mathrm{m}$ fraction at half-phi intervals, and taking a series of pipette withdrawals over a period of $8 \mathrm{hr}$. from a dispersed solution of the $<63-\mu \mathrm{m}$ fraction in a tall 1000-ml measuring cylinder.

$\mathrm{X}$-ray diffraction (XRD) analyses were carried out on the clay fractions $(<4 \mu \mathrm{m})$ after settling, separation, and preparation of oriented clay films on glass slides. Two XRD traces were run between 4 and $40^{\circ}$ $2 \theta$ for most samples, first untreated and then after glycolation overnight at $60^{\circ} \mathrm{C}$; a third slow scan run was made selectively to separate kaolinite and chlorite peaks between 24 and $26^{\circ} 2 \theta$. Focused CuK-alpha radiation was used throughout at a normal scan speed of $1^{\circ} 2 \theta /$ $\mathrm{min}$. All mineral identifications were made visually on the basis of the known d-spacings (Carver, 1971). The main clay minerals recognized were kaolinite, illite, chlorite, smectite, and an irregular mixed-layer species. Other minerals included quartz, feldspars, calcite, and dolomite. Peak heights were measured for all minerals and normalized to 100 without introducing any intensity weighting factors. The "percentages" given are therefore relative percentages for comparison within the data set.

X-ray fluorescence analyses involved preparation by air drying and grinding bulk samples. Major element analysis was by the lithium metaborate fusion technique (Walsh and Howie, 1980) and minor and trace element analysis by the hydrofluoric-perchloric acid digestion technique (Walsh and Howie, 1980). The solutions were analyzed on an emission spectrometer and the data calibrated using both igneous and sedimentary U.S. Geological Survey rock standards.

Sand fraction mineralogy was carried out by optical microscopy of separated heavy and light fraction grain mounts; separation was by settling in a solution of tetrabromoethane (specific gravity 2.96). Carbonate determinations were made on board ship by acidification using the standard DSDP carbonate bomb technique (Müller and Gastner, 1971; see Explanatory Notes, this volume).

\section{SEDIMENT FACIES}

Eight facies are recognized in Mississippi Fan sediments on the basis of lithology, sedimentary structures, composition, and texture. Of these, the calcareous biogenic sediments are volumetrically minor, but significant at certain horizons; they are divided into two facies on the basis of the carbonate content. Terrigenous sediments are dominant, and these are divided into six distinct facies, ranging from fine-grained clay and mud to coarsegrained pebbly mud and gravel. There is some gradation between facies, and all occur locally intermixed within disturbed units.

\section{Ooze and Muddy Ooze}

In this chapter, we use the terms ooze for sediments with more than $75 \%$ biogenic material and muddy ooze for those with between 50 and $75 \%$ biogenic material. This is in line with the practice adopted on some recent DSDP cruises (Legs 75 and 89) (Dean et al., 1985), and is a slight departure from the 30 and $60 \%$ class divisions recognized by DSDP (see Explanatory Notes, this volume).

Biogenic sediments are a minor but ubiquitous facies recovered as a relatively thin unit $(5-50 \mathrm{~cm})$ at the surface of most Leg 96 sites (Table 1). Staining with Rodamin B dye showed that none of the organisms recovered were living. This indicates that the very tops of the sediment sections were washed away by the drill and, therefore, the calcareous unit on the seafloor is probably slightly thicker than the core interval obtained. The facies also occurs as a 29-m-thick unit (Fig. 2A) at the base of Site 615, the deepest hole penetrated on the lower fan (see Site 615 chapter, this volume).

There is no internal bedding or other primary sedimentary structure visible in the surficial biogenic layer. The sediment is a yellowish-brown marly calcareous ooze, which appears homogeneous and is probably thoroughly bioturbated. It is very poorly sorted with a fine sand- to silt-sized biogenic component and a variable fine-silt to clay terrigenous admixture. Planktonic foraminifers are dominant, nannofossils and siliceous organisms form less than $10 \%$, and terrigenous material comprises up to $25 \%$ of the sediment. There are rare, black, authigenic ironsulphide-rich mottles present.

The light bluish gray to yellowish gray oozes recovered near the base of Site 615 are also visually relatively homogeneous and structureless. However, there are subtle grain-size variations within an overall normally graded sequence that extends through the upper $28 \mathrm{~m}$ of recovered section. This section grades from a thin $(10 \mathrm{~cm})$ coarse gravelly layer at the base, with chalk and shelfderived bioclastic debris up to $15 \mathrm{~mm}$ in size, through a shelly foraminifer-rich nannofossil ooze, to a very finegrained pure nannofossil ooze in the top several meters.

Table 1. Percentages of different facies present from the recovered section at each Mississippi Fan site.

\begin{tabular}{|c|c|c|c|c|c|c|c|c|c|}
\hline Facies/sites & Site 614 & Site 615 & Site 616 & Site 617 & Site 620 & Site 621 & Site 622 & Site 623 & Site 624 \\
\hline Oozes and muddy oozes & 0.6 & 16.5 & 0.1 & 0.1 & 0.1 & 0.2 & 0.1 & 0 & 0.03 \\
\hline Calcareous muds & 0.1 & 0.3 & 0 & 0.1 & 0 & 0 & 0 & 0 & 0 \\
\hline Clays and muds & 14.5 & 10.4 & 21.5 & 15.8 & 72.0 & 68.0 & 50.0 & 28.0 & 38.0 \\
\hline Silts and sands & 48.3 & 37.5 & 3.4 & 0 & 0 & 4.4 & 12.0 & 6.0 & 1.0 \\
\hline Muddy gravels and pebbly muds & 0 & 0 & 0 & 0 & 0 & 2.8 & 0.5 & 0 & 0 \\
\hline Gravels & 0 & 0 & 0 & 0 & 0 & 0.4 & 0 & 0 & 0 \\
\hline
\end{tabular}


A

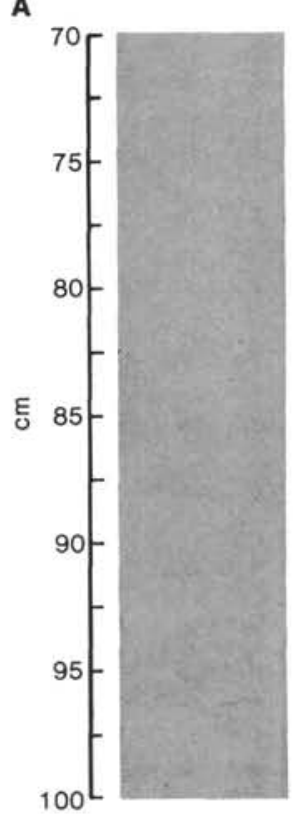

E

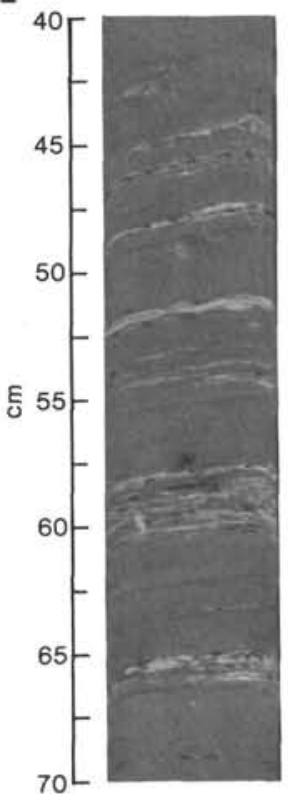

B

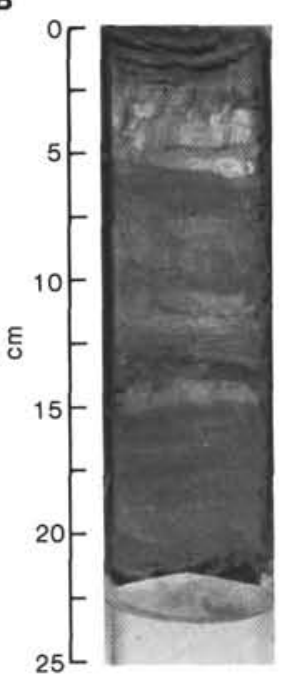

5

$\mathbf{F}$

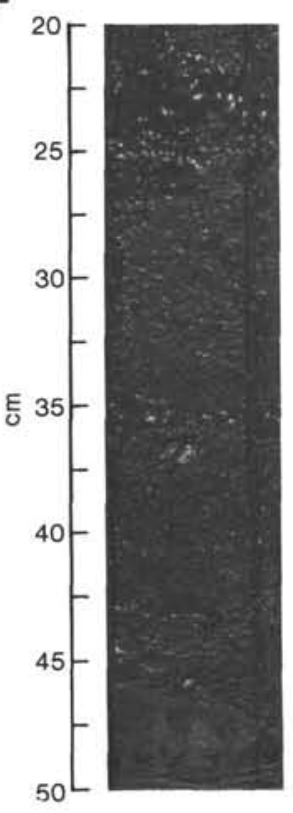

C

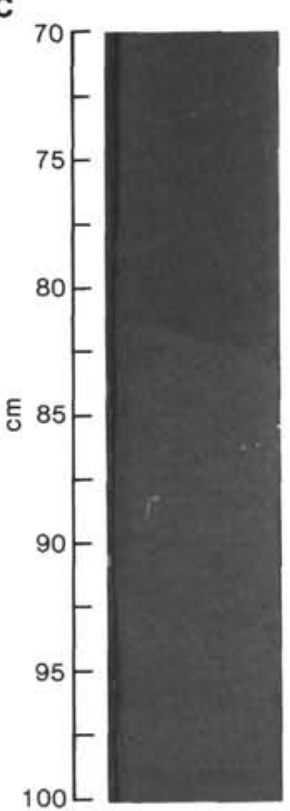

D

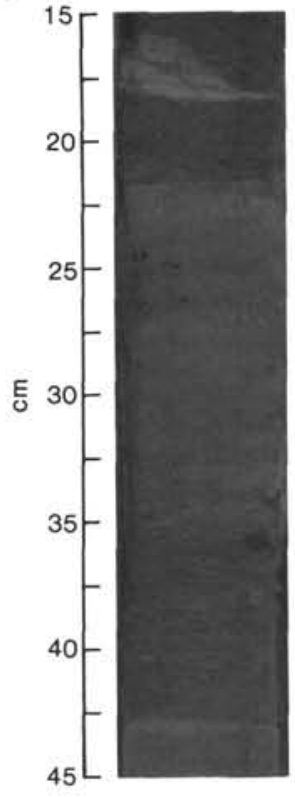

G

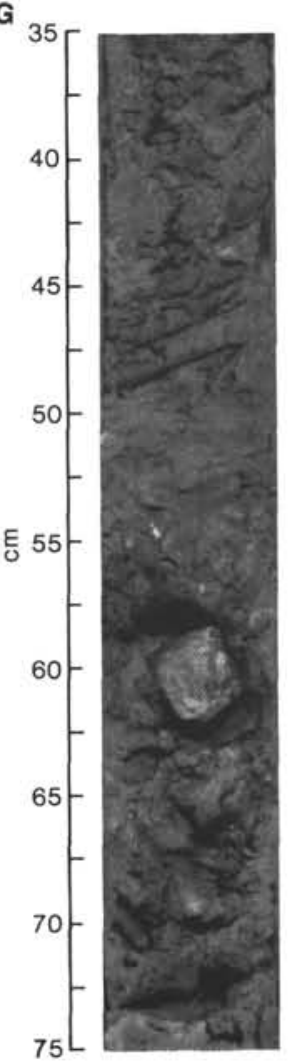

H

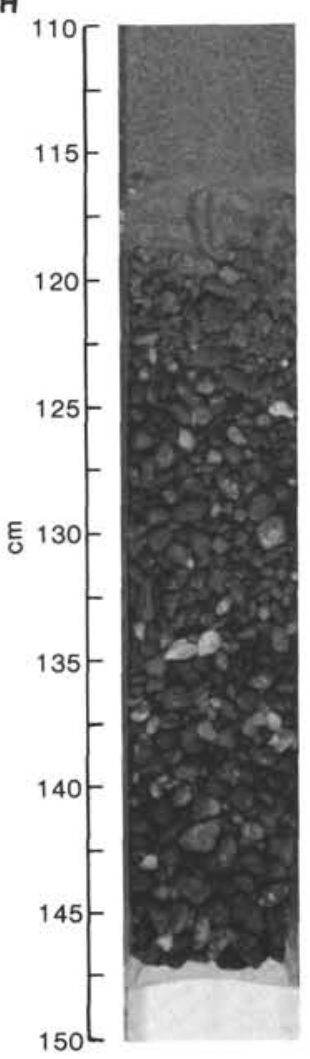

Figure 2. Photographs of each of the eight sediment facies from Mississippi fan cores. Core width in each case is about 6-7 cm. (A) Ooze, very fine grained, nannofossil dominant (Sample 615-49-4, 70-100 cm); (B) calcareous mud with irregular layering (Sample 615-52,CC); (C) mud with very thin dark mud laminae (Sample 616-28-1, 70-100 cm); (D) silty mud, poorly sorted and carbonaceous near base grading up to fine mud (Sample 615-22-2, 15-45 cm); (E) silt-laminated mud, occurring as probable graded laminated units (Sample 621-25-2, 40-70 cm); (F) sand, part of medium-thick graded sand bed (Sample 623-8-2, 20-50 cm); (G) pebbly mud (Sample 621-29-1, 35-75 cm); (H) gravel, top part of thick gravel section grading into overlying coarse-grained sand (Sample 621-33-2, 110-150 cm). 
The biogenic material consists of a high percentage of reworked Cretaceous, Pliocene, and Pleistocene forms as well as some contemporary Pleistocene planktonic forms. This sequence overlies approximately $1 \mathrm{~m}$ of veryfine-grained Pleistocene pelagic nannofossil ooze and calcareous mud without reworked fauna (see Site 615 chapter, this volume; Brooks et al., this volume).

\section{Calcareous Mud}

There is a complete gradation between the biogenic ooze and calcareous mud facies. In this chapter, calcareous mud is defined as containing $10-50 \% \mathrm{CaCO}_{3}$, a slightly greater range than the $10-30 \%$ commonly used by DSDP (Explanatory Notes, this volume). At some sites, the surficial biogenic-rich layer contains less than $50 \%$ $\mathrm{CaCO}_{3}$ (Table 1). It is structureless, fine-grained, and has a poorly sorted admixture of sand-sized planktonic foraminifers, calcareous nannofossils, rare siliceous biogenic forms, and terrigenous silt and mud.

The lowermost $50 \mathrm{~cm}$ of recovered section at Site 615 is a brownish colored calcareous mud with up to $15 \%$ foraminifers and nannofossils that immediately underlies the 29-m-thick nannofossil ooze (Fig. 2B). It is mainly structureless or, in part, indistinctly laminated.

\section{Clay and Mud}

This facies represents the very finest-grained sediments recovered (Fig. 2C), including fine mud and true clay having between 60 and $90 \%$ clay-sized fraction $(<4 \mu \mathrm{m})$ and generally less than $0.5 \%$ sand-sized material $(>63$ $\mu \mathrm{m})$. They are most common in the upper portions of the midfan channel sites (621 and 622) and in the distal overbank site (620). These sediments occur in thin to very thick units (from a few centimeters to tens of meters thick), commonly without any clear bedding or primary sedimentary structures. Bioturbational mottling, however, is rare so that the homogenity of this facies appears to be primary. In other cases, there are rare, very thin silt laminae or distinct color banding, commonly accentuated by dark-colored, iron-sulphide-rich, bioturbationally mottled layers. Other of the apparently structureless muds have a very subtle, regular banding only evident on close inspection or on X-radiographs (Coleman, Bouma, et al., this volume).

These clays and muds are dominantly terrigenous (quartz, feldspar, and clay minerals), with a small $(<5 \%)$ percentage of calcareous nannofossils, including both contemporary Pleistocene and reworked Pliocene forms. In the upper parts of the midfan channel sites (621 and 622), they locally occur as dark-colored, gas-disrupted muds.

\section{Silty Mud and Muddy Silt}

The coarser grained muds and poorly sorted silts form a facies gradational with the finer clays and muds. They occur at all sites (Table 1), being slightly more common in lower than in middle fan sites. They contain between 10 and $60 \%$ clay and up to about $5 \%$ sand. This sedimentary facies forms beds from about $5 \mathrm{~cm}$ to a meter or more in thickness, or occurs as very thick (several meters), essentially unbedded, visually structureless intervals. Silt-sized quartz and clay minerals are the domi- nant components, with minor feldspar, carbonate grains, micas, lignite, and heavy minerals. Many of the grains appear to be partially altered or coated with iron oxides.

This facies also includes distinctive dark-colored, lignite-bearing silty mud beds which range from about 5 to $50 \mathrm{~cm}$ in thickness. These lignite-bearing beds occur in three main types: (1) completely structureless with gradational contacts; (2) organized into distinct beds, in some cases with indistinct normal grading and floating mud clasts; and (3) as clearly graded beds, commonly forming part of a thicker bed graded from laminated silt or sand at the base to fine-grained homogeneous mud or clay at the top (Fig. 2D).

\section{Silt-Laminated Mud}

The most common sediments at many of the sites, especially the midfan overbank and lower fan channellevee sites (Table 1), are silt-laminated muds. These occur over intervals of a few centimeters to a few tens of meters in thickness, and range from uniform mud with only 5 to $10 \%$ thin silt laminae to mud with over $50 \%$ silt laminae and thin silt beds. The frequency of visually observable laminae may reach 400-500 per meter of section. However, the very thin silt laminae are difficult to resolve visually and are best seen on X-radiographs (Coleman, Bouma, et al., this volume). The thicker laminae commonly show internal parallel lamination or microcross-lamination and slight normal grading. The bases are commonly sharp, and locally scoured, loaded with flame structures; the tops may be sharp or gradational.

In many cases, the laminae are more or less regularly spaced and apparently ungrouped. However, at least three types of groupings or graded laminated units could be recognized (Fig. 2E), each ranging from about 3 to 10 $\mathrm{cm}$ in total thickness: (1) units of up to 10 to 15 laminae that show a regular upward decrease in thickness and grain size of laminae; (2) units with fewer silt laminae that grade upward through gray, reddish, and gray black mottled mud, and (3) more irregular units with discontinuous and lenticular laminae showing load, flame, and microslump structures indicative of very rapid deposition.

This facies is compositionally and texturally very similar to the silty mud and muddy silt facies, being fine grained and dominantly terrigenous, but with a much better sorting in terms of separation of the silt and clay fractions. The silts locally include significant angular detrital carbonate and, more rarely, volcanic ash.

\section{Silt and Sand}

Silts and sands are a very common facies in parts of the fan, especially lower fan Sites 614 and 615 (Table 1), and occur in intervals from less than $10 \mathrm{~cm}$ to over $10 \mathrm{~m}$ in thickness. Sand loss by wash out and section increase by flow-in during the coring process means that some of the thickest $(1.5-10 \mathrm{~m})$ sandy intervals recovered probably do not represent single bed thicknesses.

Many of the beds show clear positive grading (Fig. $2 \mathrm{~F}$ ). The thicker beds are otherwise apparently structureless, whereas most of the thinner sand and silt beds show some internal sedimentary structures. These are commonly 
organized in partial Bouma $T_{a}$ to $T_{e}$ sequences (Bouma, 1962) with massive, parallel, and cross-laminated divisions. The bottom contacts are invariably sharp and commonly loaded or scoured; the upper contacts are either sharp or gradational.

Grain size varies both within and between beds. The maximum size at the base of the thicker beds is as much as $5 \mathrm{~mm}$ (pebble sized); the mean size is most commonly fine to medium sand $(125-250 \mu \mathrm{m})$, and there is a high proportion of silt. The larger grains are commonly well rounded, spherical or elongate, and highly polished. The thinner beds tend to be better sorted, medium to coarse silt sized (16-63 $\mu \mathrm{m})$, with a maximum size rarely exceeding $150 \mu \mathrm{m}$ (fine sand). The finer grains are often highly angular and irregular in shape. There are rare medium to coarse-grained thin sand beds.

The sands and silts are dominantly terrigenous and quartzose with minor biogenic material.

\section{Muddy Gravel and Pebbly Mud}

This is a relatively rare facies (Table 1) encountered only at the two midfan channel sites (Sites 621 and 622) in intervals up to $4 \mathrm{~m}$ thick (Fig. 2G). Pebbles are as much as several centimeters in diameter, very poorly sorted, and set in a clay-silt-sand matrix. There are no bedding or interval structures evident. Clasts include chert, quartz, jasper, mudstone, and shell fragments.

\section{Gravel}

Apparently clast-supported gravel was recovered only in a $60-\mathrm{cm}$-thick section near the base of Site 621 in the channel thalweg (Fig. 2H) (see Site 621 chapter, this volume) (Table 1). Clasts range up to $3 \mathrm{~cm}$ in size, are poorly sorted, and have a composition similar to those of the pebbly mud facies. The clasts are mostly rounded to subrounded in shape, and show an abrupt grading over a few centimeters into overlying medium-grained sands. The coring process may have washed out any fine-grained matrix and disturbed any original structure that may have been present.

\section{SEDIMENT COMPOSITION}

There is a broad compositional similarity of sediments within any one facies as well as between many of the facies. This uniformity is reflected in the sand and silt mineralogy (determined by thin-section and grain-mount analyses), clay mineralogy (determined by X-ray diffraction analyses), inorganic geochemistry (from X-ray fluorescence spectrometry), and carbonate content (from carbonate bomb analyses).

\section{Sand and Silt Mineralogy}

The sand and sandy silt beds are uniformly terrigenous (95-98\%). Quartz is the dominant mineral, with secondary feldspars, micas, and carbonates, and accessory heavy minerals, glauconite, and lithic fragments. The heavy mineral suite commonly includes amphiboles, pyroxenes, epidote, zircon, tourmaline, and opaque grains. The small biogenic fraction (2-5\%) comprises foraminifers, shallow-water shell debris, and lignitic material.
The generally finer-grained thin silt laminae show a similar composition to the thicker sand beds but commonly have, in addition, a variable and significant proportion (10-25\%) of clastic carbonate material of undetermined origin, and relatively less quartz silt. The silt laminae, as well as the dispersed silt fraction of the silty mud and muddy silt facies, appear relatively richer than the coarser-grained sands in altered or iron-stained grains of indeterminate composition. Volcanic ash is locally important.

\section{Clay Mineralogy}

The $<4 \mu \mathrm{m}$ size fraction from all eight facies (120 samples) was analyzed by X-ray diffraction, and estimates of relative mineral abundances were made from peak-height measurements; the data are given in Pickering and Stow (this volume). Of the four main clay minerals identified, smectite is generally most abundant $(30-50 \%)$, kaolinite and chlorite are next (10-20\%), and illite is least abundant $(5-15 \%)$. Also found within the clay-sized fraction are quartz (3-10\%), feldspar (1-5\%), and up to a few percent calcite and dolomite. The claysized fraction analyzed from the carbonate-ooze facies near the base of Site 615 consists mostly of calcite (65$85 \%$ ); aragonite is variably present in minor quantities (3-7\%) (Pickering and Stow, this volume).

The actual ranges of clay mineral abundances are quite large (Figs. 3, 4, 5), although it is difficult to correlate this variability with differences in facies or location on

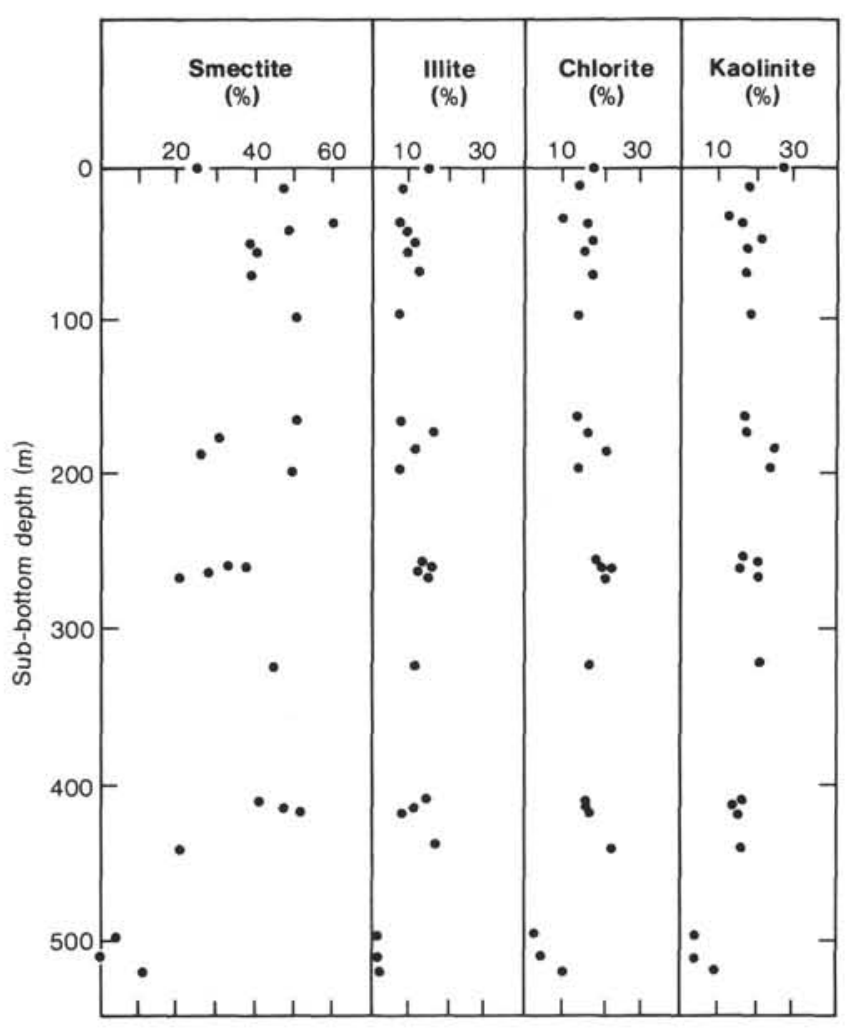

Figure 3. Downhole trends of relative clay mineral percentages within the clay-sized fraction $(<4 \mu \mathrm{m})$ at Site 615 in the lower Mississippi Fan lobe region. 


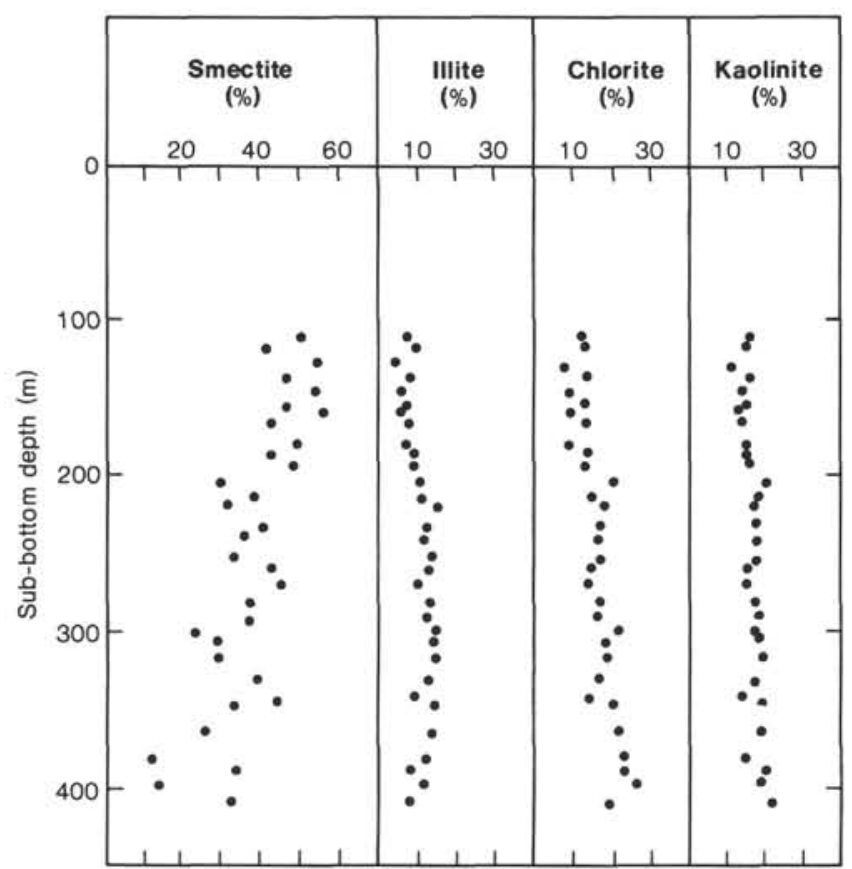

Figure 4. Downhole trends of relative clay mineral percentages within the clay-sized fraction $(<4 \mu \mathrm{m})$ at Site 620 in the midfan overbank region.

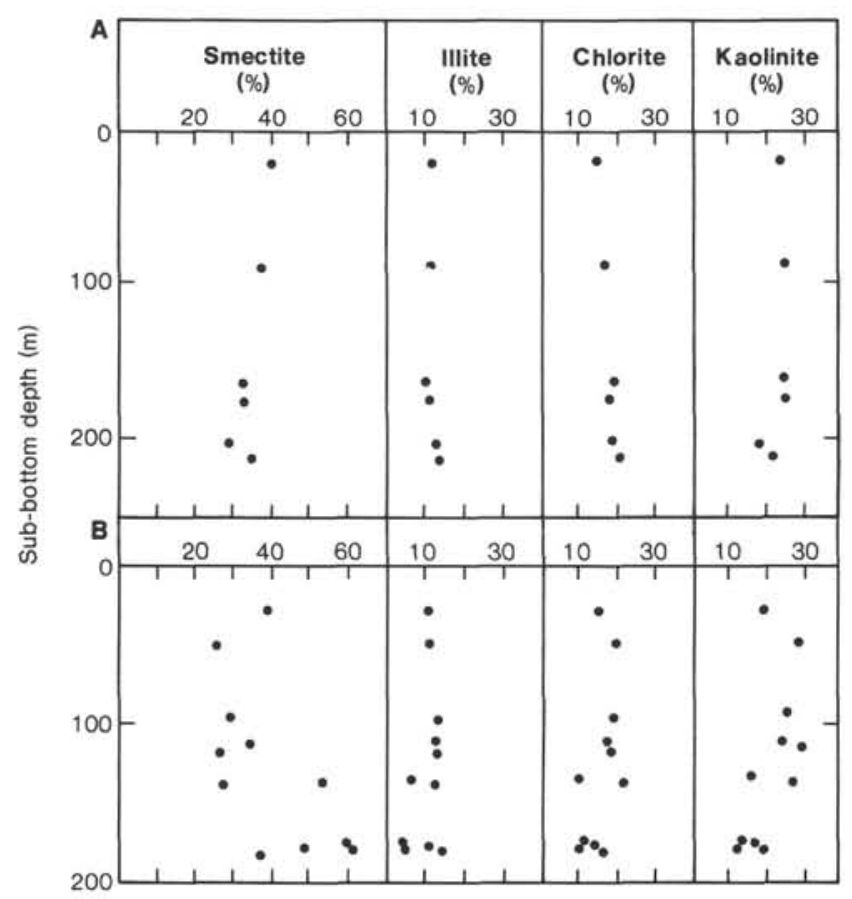

Figure 5. Downhole trends of relative clay mineral percentages within the clay-sized fraction $(<4 \mu \mathrm{m})$ at sites in the midfan channel. (A) Site 621; (B) Site 622.

the fan. The only apparent facies differences are for (1) oozes and muddy oozes, which show relatively greater calcite and aragonite and (2) thick sands, which have relatively greater quartz and feldspar, a higher chlorite to kaolinite ratio, and a generally smaller proportion of clay-sized material. It is partly these facies differences that are also reflected in the observed regional variations. These regional differences show the lower fan sites to have relatively more quartz and feldspar than the midfan sites (i. e., a greater proportion of sand-silt facies), and the midfan overbank sites to have relatively more carbonate than the midfan channels or the lower fan sites. (Figs. 3, 4, 5).

\section{Inorganic Geochemistry}

Inorganic geochemical data from 149 ground wholerock samples are presented in Pickering and Stow (this volume). The "average" composition of major element oxides from these analyses is $\mathrm{SiO}_{2}(50-60 \%), \mathrm{Al}_{2} \mathrm{O}_{3}(10-$ $15 \%), \mathrm{FeO} / \mathrm{Fe}_{2} \mathrm{O}_{3}(4-6 \%), \mathrm{MgO}(2-3 \%), \mathrm{CaO}(2-4 \%)$, $\mathrm{Na}_{2} \mathrm{O}(2 \%), \mathrm{K}_{2} \mathrm{O}(2-5 \%)$, and minor amounts of $\mathrm{MnO}$, $\mathrm{TiO}_{2}$, and $\mathrm{P}_{2} \mathrm{O}_{5}$. The $\mathrm{SiO}_{2}$ abundance varies more widely than indicated above, but in inverse relationship with $\mathrm{CaO}$ and $\mathrm{Al}_{2} \mathrm{O}_{3}$. Trace element abundances measured are all relatively low on average compared with data from other deep-sea sediments (Arthur, 1979; Dean and Parduhn, 1984).

Plots of downhole trends of major and trace element abundances and their variation with depth at the lower fan Site 615 are shown in Figure 6. Site 615 has been selected for this chapter, partly as representative of all the sites and partly as the deepest hole drilled. Data from all other sites are plotted in Pickering and Stow (this volume). The following points from the Site 615 data are worth emphasizing: (1) The cluster of points at around 500-m depth are all distinctive and are all from sediment of the calcareous ooze facies. (2) The general broad scatter of values through much of the cored intervals is significantly greater than for the middle fan sites analyzed (Pickering and Stow, this volume). This is probably partly due to greater interbedded facies variation at Site 615 . (3) The range of scatter appears to be greatest in the top $100 \mathrm{~m}$ of section. The reason for this is not entirely clear, although it may reflect variation in facies types, sedimentation rates, and chemical mobility during early diagenesis.

\section{Carbonate Content}

The percentage of carbonate was measured for over 200 samples and shows wide variation from 0 to more than $80 \%$ (see site chapters, this volume). Following the classification scheme of Dean et al. (1985), our calcareous oozes contain over $75 \%$ carbonate, the muddy oozes have an admixture of up to $50 \%$ terrigenous material, and the calcareous muds range from 10 to $50 \%$ carbonate. The carbonate component is dominantly pelagic foraminifers and nannofossils, although benthic foraminifers and shallow water shell debris are also present in the resedimented ooze near the base of Site 615 .

The terrigenous facies mostly contain less than $10 \%$ carbonate (rarely up to $18 \%$ ), and this component is a mixture of mainly reworked pelagic biogenics and carbonate silt of indeterminate origin. The lower fan sites (614 and 615) average $2.8 \%$ and the midfan channel sites (621 and 622) $3.7 \%$ carbonate, whereas the overbank sites on the midfan (Sites 616, 617, and 620) and the channel-levee sites on the lower fan (Sites 623 and 624) 


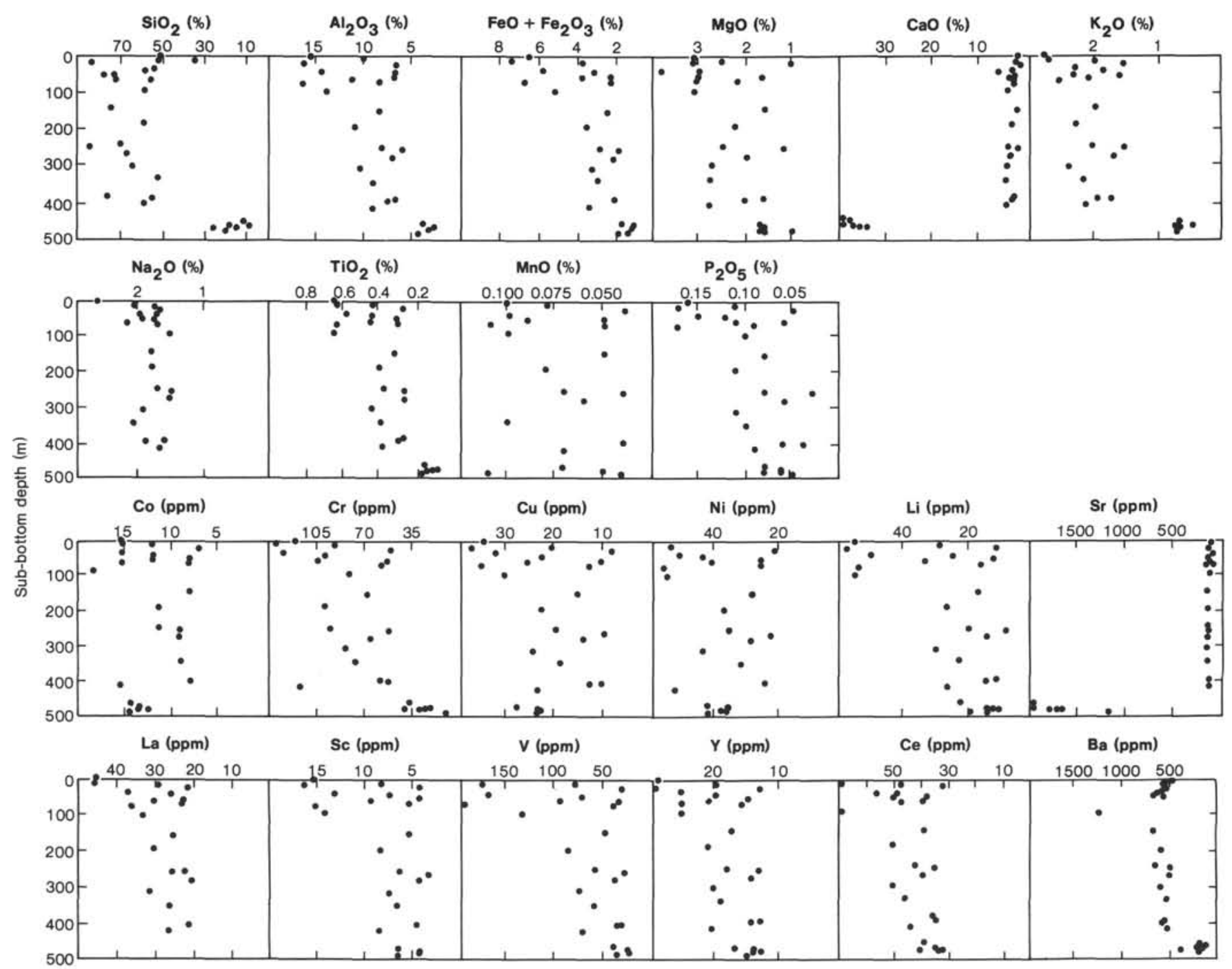

Figure 6. Downhole trends of major and trace elements from powdered whole sediment samples collected at lower fan Site 615. (From Pickering and Stow, this volume.)

average around $8 \%$ carbonate (Fig. 7). These apparent regional differences may be related to facies differences, because there is less carbonate in both the silt-sand and clay-mud facies than in the silt-laminated mud facies. Isolated peaks in carbonate content (e.g., at around 50$\mathrm{m}$ depth at Site 616, and about 125 -m depth at Site 615) are most likely also due to facies variation. They indicate either a greater abundance of silt laminae with detrital carbonate silt, or a local increase in pelagic carbonate background sedimentation.

\section{SEDIMENT TEXTURE}

The grain size characteristics described above for each of the separate facies were determined from 120 granulometric analyses using the sieve and pipette method (Table 2). The differences between sedimentary facies are clearly distinguished using either a triangular plot of sandsilt-clay percentage (Fig. 8A) or typical cumulative frequency curves (Fig. 8B). The thick-bedded coarser-grained sand and finest-grained clay are both relatively well sorted but with a distinct fine tail (hyperbolic curve). The silt-laminated mud appears less well sorted with a broad fine tail (hyperbolic-logarithmic curve), although individual silt and mud laminae show much better sorting when analyzed separately. The silty mud facies are poorly sorted with a broad coarse tail (parabolic-logarithmic curve). Only a few analyses are presently available for the ooze and calcareous mud facies, and these generally show an irregular very poorly-sorted distribution (logarithmic tending curve).

More detailed grain size plots are shown for selected middle and lower fan samples as smoothed frequency histograms in Figure 9. These plots show the following: (1) The coarsest modal size measured for the sand facies is about $500 \mu \mathrm{m}$, whereas most layers range between 150 and $360 \mu \mathrm{m}$ (fine to medium grained) (Figs. 9A-D). (2) The silty-mud and muddy-silt facies have broad modal peaks between 16 and $64 \mu \mathrm{m}$, are much more poorly sorted than the sands, and have a larger fine tail (Figs. 9E, $\mathrm{G}, \mathrm{H})$. They appear to be gradational into the fine siltysand facies (muddy sands in Fig. 9K). (3) Several examples of thick sand beds have been serially analyzed from 
D. A. V. STOW ET AL.

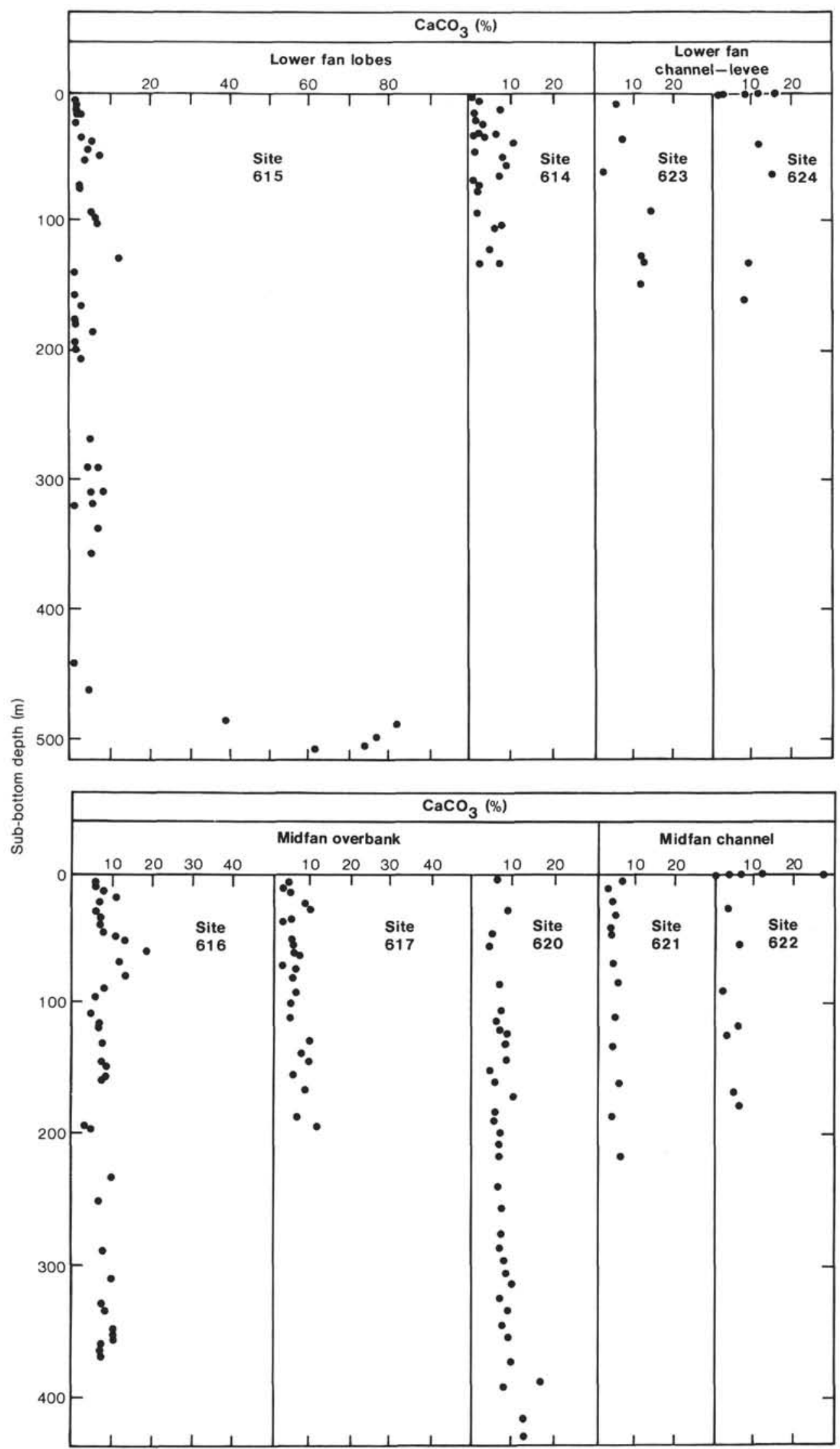

Figure 7. Downhole trends of carbonate content from shipboard carbonate bomb analyses of Mississippi Fan sediments. (Data given in site chapters, this volume.) 
Table 2. Grain-size data for Mississippi Fan sediments.

\begin{tabular}{cccccc}
\hline $\begin{array}{c}\text { Core-Section } \\
(\text { interval in cm) }\end{array}$ & $\begin{array}{c}\text { Sub-bottom } \\
\text { depth }(\mathrm{m})\end{array}$ & $\begin{array}{c}\text { Sand } \\
(\%)\end{array}$ & $\begin{array}{c}\text { Silt } \\
(\%)\end{array}$ & $\begin{array}{c}\text { Clay } \\
(\%)\end{array}$ & Facies \\
\hline
\end{tabular}

Hole 614

$\begin{array}{lrrrrr}1-3,93-95 & 3.92 & 0.2 & 11.4 & 88.4 & \text { Clay } \\ 2-6,62-94 & 17.56 & 34.4 & 16.1 & 49.5 & \text { Sand } \\ 5-1,110-112 & 30.13 & 53.4 & 20.6 & 26.0 & \text { Sand } \\ 5-2,100-102 & 31.52 & 56.7 & 13.6 & 29.7 & \text { Sand } \\ 5-4,100-102 & 34.52 & 52.5 & 12.1 & 35.4 & \text { Sand }\end{array}$

Hole 614A

$\begin{array}{lrrrrl}2-1,11-13 & 45.14 & 2.4 & 58.8 & 38.8 & \text { Slt-md } \\ 3-5,30-32 & 60.63 & 57.8 & 18.7 & 23.5 & \text { Sand } \\ 4-1,50-52 & 61.33 & 65.6 & 13.6 & 20.8 & \text { Sand } \\ 8-1,62-64 & 99.15 & 0.7 & 16.2 & 83.1 & \text { Lam } \\ 8-3,32-34 & 101.85 & 82.1 & 15.0 & 2.9 & \text { Sand } \\ 9-1,42-44 & 108.45 & 82.0 & 17.2 & 0.8 & \text { Sand } \\ 9-1,80-82 & 108.82 & 80.6 & 18.6 & 0.8 & \text { Sand } \\ 9-2,12-14 & 109.65 & 80.0 & 18.3 & 1.7 & \text { Sand }\end{array}$

Hole 615

$\begin{array}{lr}1-1,60-62 & 0.63 \\ 3-2,55-57 & 14.17 \\ 5-4,62-64 & 38.14 \\ 6-4,85-87 & 47.88 \\ 6-C C, 0-2 & 51.53 \\ 7-6,48-50 & 56.41 \\ 9-2,37-39 & 69.21 \\ 12-1,50-52 & 96.70 \\ 19-1,100-102 & 163.21 \\ 20-1,57-59 & 172.28 \\ 21-1,27-29 & 181.49 \\ 22-4,62-64 & 195.83 \\ 29-1,68-70 & 257.89 \\ 29-2,70-72 & 259.41 \\ 29-3,70-72 & 260.91 \\ 29-5,70-72 & 263.91 \\ 34-1,130-132 & 315.53 \\ 43-1,40-42 & 409.63 \\ 43-3,40-42 & 412.63 \\ 43-3,80-82 & 413.03 \\ 43-5,40-42 & 415.63 \\ 46-C C, 11-13 & 428.58 \\ 56-3,80-82 & 489.03 \\ 50-C C, 20-22 & 494.60 \\ 52-1,23-25 & 504.46\end{array}$

$\begin{array}{rrrl}0.1 & 20.0 & 79.9 & \text { Clay } \\ 1.5 & 19.7 & 78.8 & \text { Lam } \\ 6.6 & 24.6 & 68.8 & \text { Lam } \\ 1.0 & 95.6 & 3.4 & \text { Sand } \\ 59.3 & 35.8 & 4.7 & \text { Sand } \\ 44.6 & 44.7 & 10.7 & \text { Sand } \\ 61.0 & 33.3 & 5.7 & \text { Sand } \\ 0.9 & 68.6 & 30.5 & \text { Lam } \\ 7.6 & 54.8 & 37.6 & \text { Slt-md } \\ 56.5 & 34.9 & 8.6 & \text { Slt-md } \\ 73.7 & 18.0 & 8.3 & \text { Slt-md } \\ 24.7 & 42.0 & 28.3 & \text { Slt-md } \\ 65.2 & 26.9 & 7.9 & \text { Slt-md } \\ 89.6 & 10.4 & 0 & \text { Sand } \\ 92.4 & 7.6 & 0 & \text { Sand } \\ 83.4 & 12.9 & 3.7 & \text { Sand } \\ 12.7 & 63.7 & 23.6 & \text { Sand } \\ 79.8 & 17.7 & 2.5 & \text { Sand } \\ 67.1 & 28.5 & 4.4 & \text { Sand } \\ 63.4 & 30.6 & 6.0 & \text { Sand } \\ 63.7 & 33.1 & 3.2 & \text { Sand } \\ 53.4 & 34.0 & 12.6 & \text { Slt-md } \\ 7.0 & 52.7 & 42.3 & \text { Ooze } \\ 38.0 & 35.5 & 26.5 & \text { Ooze } \\ 34.1 & 22.9 & 43.0 & \text { Calc }\end{array}$

Hole 616

$\begin{array}{lr}2-6,20-22 & 13.72 \\ 7-1,30-32 & 53.92 \\ 10-1,71-73 & 83.34 \\ 17-3,34-36 & 155.36 \\ 21-1,46-48 & 190.68 \\ 28-1,12-14 & 305.45 \\ 33-C C, 21-23 & 357.34 \\ 34-1,93-95 & 362.64\end{array}$

$\begin{array}{rrrl}0.1 & 28.6 & 71.3 & \text { Lam } \\ 0.1 & 20.6 & 79.3 & \text { Lam } \\ 0.1 & 43.1 & 56.8 & \text { Lam } \\ 6.8 & 24.9 & 63.3 & \text { Slt-md } \\ 47.9 & 24.6 & 27.5 & \text { Sand } \\ 0.2 & 25.8 & 74.0 & \text { Clay } \\ 61.0 & 33.1 & 5.9 & \text { Sand } \\ 0.1 & 35.8 & 64.1 & \text { Clay }\end{array}$

Hole 617

$\begin{array}{lrllll}1-1,90-92 & 0.91 & 0 & 53.1 & 46.9 & \text { Slt-md } \\ 3-6,60-62 & 25.72 & 0 & 25.5 & 74.5 & \text { Lam } \\ 5-1,28-30 & 37.09 & 0.2 & 46.6 & 53.2 & \text { Lam } \\ 6-3,50-52 & 49.82 & 0.3 & 62.8 & 36.9 & \text { Lam } \\ 11-1,44-46 & 94.57 & 0.5 & 39.4 & 60.1 & \text { Slt-md } \\ 15-2,16-18 & 133.88 & 1.1 & 28.8 & 70.1 & \text { Lam }\end{array}$

Hole 620

\begin{tabular}{llllll}
$14-2,60-62$ & 119.13 & 0.1 & 34.1 & 65.8 & Lam \\
$16-2,60-62$ & 138.33 & 0.1 & 23.6 & 76.3 & Clay \\
$17-6,60-62$ & 153.92 & 0.1 & 23.3 & 76.6 & Clay \\
$19-1,60-62$ & 165.63 & 0.1 & 43.6 & 56.3 & Lam \\
$21-2,60-62$ & 186.13 & 0.1 & 26.8 & 73.1 & Clay \\
$23-2,59-61$ & 204.91 & 0.1 & 30.4 & 69.5 & Clay \\
$25-1,50-52$ & 222.31 & 0.1 & 45.8 & 54.1 & Lam \\
$27-1,60-62$ & 241.52 & 0.1 & 35.4 & 64.5 & Lam \\
\hline
\end{tabular}

Table 2 (continued).

\begin{tabular}{cccccc}
\hline $\begin{array}{c}\text { Core-Section } \\
\text { (interval in cm) }\end{array}$ & $\begin{array}{c}\text { Sub-bottom } \\
\text { depth }(\mathrm{m})\end{array}$ & $\begin{array}{c}\text { Sand } \\
(\%)\end{array}$ & $\begin{array}{c}\text { Silt } \\
(\%)\end{array}$ & $\begin{array}{c}\text { Clay } \\
(\%)\end{array}$ & Facies \\
\hline Hole 620 (Cont.) & & & & & \\
& & & & & \\
$29-1,60-62$ & 260.72 & 0.4 & 58.1 & 41.5 & Lam \\
$31-2,60-62$ & 281.42 & 0.1 & 28.7 & 71.2 & Clay \\
$33-2,60-62$ & 300.63 & 0.1 & 29.1 & 70.8 & Clay \\
$35-2,60-62$ & 319.83 & 0.1 & 27.8 & 72.3 & Clay \\
$37-2,60-62$ & 339.03 & 0.9 & 42.9 & 56.2 & Clay \\
$40-2,60-62$ & 367.63 & 0.2 & 28.6 & 71.6 & Clay \\
$42-2,60-62$ & 386.63 & 2.3 & 30.0 & 67.7 & Clay \\
$44-3,60-62$ & 407.13 & 0.4 & 29.0 & 70.6 & Clay \\
& & & & & \\
Hole 621 & & & & & \\
& & & & & \\
$4-1,60-62$ & 23.33 & 3.4 & 32.1 & 64.5 & Slt-md \\
$14-4,60-62$ & 91.82 & 2.4 & 40.1 & 57.5 & Slt-md \\
$26-1,73-75$ & 167.05 & 27.1 & 32.6 & 40.3 & Slt-md \\
$27-1,90-92$ & 176.82 & 1.1 & 37.4 & 61.5 & Lam \\
$32-1,90-92$ & 202.23 & 0.4 & 37.4 & 62.2 & Lam \\
$33-2,90-92$ & 213.82 & 98.8 & 1.2 & 0 & Sand
\end{tabular}

Hole 622

$\begin{array}{lrrrrl}4-2,60-62 & 24.83 & 3.0 & 33.9 & 63.1 & \text { Clay } \\ 6-4,60-62 & 46.82 & 1.2 & 30.3 & 68.5 & \text { Clay } \\ 10-3,60-62 & 93.02 & 0.2 & 27.5 & 72.3 & \text { Clay } \\ 12-1,60-62 & 109.13 & 0.1 & 28.7 & 71.2 & \text { Clay } \\ 13-3,60-62 & 115.93 & 0.1 & 30.9 & 69.0 & \text { Lam } \\ 16-1,60-62 & 133.52 & 0.8 & 80.5 & 18.7 & \text { Sand } \\ 16-2,60-62 & 135.02 & 0.2 & 57.5 & 42.3 & \text { Lam } \\ 22-1,60-62 & 175.33 & 9.1 & 77.7 & 13.2 & \text { Sand } \\ 22-2,60-62 & 176.83 & 24.3 & 68.9 & 6.8 & \text { Sand } \\ 23-1,65-67 & 178.38 & 31.1 & 62.5 & 6.4 & \text { Sand } \\ 23-2,65-67 & 179.88 & 85.5 & 11.0 & 3.5 & \text { Sand }\end{array}$

Hole 623

$\begin{array}{lrrrrl}1-4,90-92 & 5.43 & 3.2 & 19.9 & 76.9 & \text { Lam } \\ 2-6,60-62 & 14.73 & 0.1 & 17.1 & 82.8 & \text { Clay } \\ 3-5,60-62 & 22.83 & 0.1 & 15.9 & 84.0 & \text { Clay } \\ 5-1,60-62 & 36.03 & 0.2 & 22.4 & 77.4 & \text { Clay } \\ 6-2,60-62 & 47.13 & 0.1 & 26.0 & 73.9 & \text { Lam } \\ 7-3,60-62 & 58.22 & 34.0 & 44.3 & 21.7 & \text { Slt-md } \\ 9-2,60-62 & 75.93 & 2.6 & 51.3 & 46.1 & \text { Lam } \\ 11-2,60-62 & 95.13 & 1.3 & 65.2 & 33.5 & \text { Lam } \\ 12-2,60-62 & 104.73 & 0.3 & 8.4 & 91.3 & \text { Clay } \\ 14-1,59-61 & 122.01 & 0.1 & 10.0 & 89.9 & \text { Clay } \\ 16-2,60-62 & 142.23 & 34.5 & 22.4 & 42.8 & \text { Slt-md } \\ & & & & & \end{array}$

Note: Lithofacies type for each sample is shown in the right-hand column. Abbreviations as follows: Ooze = oozes and muddy oozes; Calc $=$ calcareous muds; Clay $=$ clays and muds; Slt - md $=$ silty muds and muddy silts; Lam $=$ silt-laminated muds; Sand $=$ silts and sands.

base to top and most of these show slight but distinct normal grading of about 1 to $1.5 \phi$ intervals over 1 to $3 \mathrm{~m}$ of section (Figs. 9A-C). This grading occurs in the upper parts only of the 10-m-thick sand beds recovered. (4) The silt-laminated muds, where well-laminated, show distinct silt modes generally between 20 and $30 \mu \mathrm{m}$ and a relatively large fine tail. Where they are less laminated, with either thinner and/or less abundant laminae, the silt mode is less distinct and commonly finer grained $(8-20 \mu \mathrm{m})$ (Fig. 9H) These facies are gradational to the non-laminated, structureless, or homogeneous clay and mud facies which show an even size distribution and no silt mode (Figs. 9E-I). (5) Preliminary analyses from near the base and near the middle part of the very thick, possibly resedimented, carbonate ooze unit near the base of Site 615 (Fig. 9I) show distinct modes, evidence of 
A
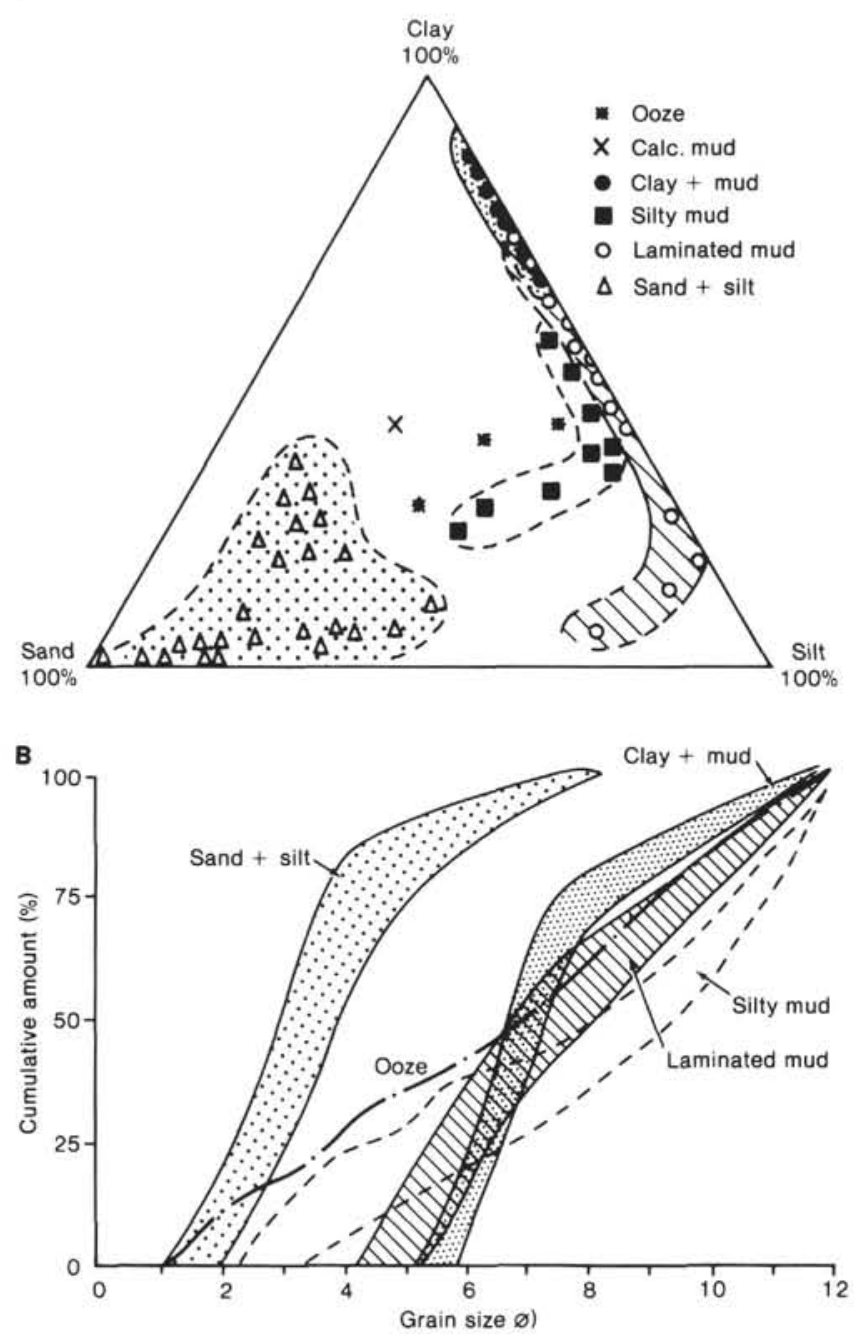

Figure 8. Grain-size characteristics of Mississippi Fan lithofacies: (A) triangular plot of sand-silt-clay content; (B) typical cumulative frequency curves for different facies.

sorting and normal grading. These features support the inference that it originated from a single resedimentation event. Insufficient samples were taken of the gravel facies at the base of the channel axis Site 621 for a statistically valid grain size analysis. However, the gravel is generally poorly sorted with no clear mode, and clast sizes range from a few millimeters to a few centimeters.

\section{DISCUSSION}

\section{Facies Interpretation}

Apart from the thin surface layer of calcareous muds and oozes, slowly deposited by pelagic and hemipelagic settling, most of the sediment recovered from the Mississippi Fan during Leg 96 shows evidence of resedimentation from shallower water. This evidence includes: (1) the very rapid rates of sedimentation $(6-12 \mathrm{~m} / 1000 \mathrm{yr}$.) (Wetzel and Kohl, this volume; site chapters, this volume); (2) the dominant terrigenous composition with land-derived plant material and a sparsity of contempo- rary planktonic tests; (3) the abundance of primary sedimentary structures suggesting deposition from turbidity currents, debris flows, or sediment slides (see site chapters, this volume; Cremer and Stow, this volume; Coleman, Bouma, et al., this volume); and (4) the almost complete absence of secondary biogenic structures.

In detail, however, there are certain aspects of these resedimented facies that still require further interpretation. The clays and muds, although very rapidly deposited, are commonly structureless with little evidence of the type of flow from which they were deposited. Only in some cases do very thin, darker mud laminae occur at a spacing of 1 to $3 \mathrm{~cm}$ through several meters of section. These appear to be primary in origin, rather than caused by coring disturbance (Cremer and Stow, this volume), and are similar to the thick-bedded unifite muds of Stanley (1981), perhaps representing deposition from very large, slump-derived, muddy turbidity currents. In other cases, there is color banding on a centimeter to decimeter scale, with irregular dark iron-sulphide mottling that suggests bioturbational activity. The sediments may have been deposited partly as thin-bedded mud turbidites and partly from river-flood-derived hemipelagic suspensions (Stow and Piper, 1984).

The silty mud and muddy silt facies are also partly enigmatic in their origin. Where graded, they are similar to the disorganized turbidites of Stow and Piper (1984), perhaps resulting from very rapid deposition or from a poorly developed turbidity current. Where structureless, they might better be interpreted as having settled out of concentrated hemipelagic suspensions, although sedimentation rates may be too great to support this interpretation. In contrast, the silt-laminated muds show clear evidence of deposition from normal low-concentration turbidity currents, having many of the characteristics of fine-grained turbidites (Piper, 1978; Stow and Shanmugam, 1980; Stow and Piper, 1984).

The thin- to very thick-bedded silts and sands commonly show evidence of deposition from high-concentration turbidity currents (Bouma, 1962; Stow, 1985). The thicker beds have perhaps been influenced by grain flow or fluidized flow in the final stages of deposition (Walker, 1978). The structureless aspect of many of these thick sands and the possibility of coring disturbance makes conclusive interpretation difficult. The apparent graded top of the lone gravel unit from the channel thalweg Site 621 also suggests turbidity current transport, whereas the pebbly muds presumably were deposited from debris flows (Stow, 1985).

Mass movement is exhibited as local small-scale overturned folds and microfaults most commonly in the midfan levee site (617) and less frequently within the channel and in the lower fan margin sites (see site chapters, this volume; Cremer and Stow, this volume; Coleman, Bouma, et al., this volume). The top $90 \mathrm{~m}$ of the section at Site 616 has undergone mass movement, as indicated by highly inclined lamination, overturned folds, and possible repeated sections. It is not yet clear whether this is indeed a single far-traveled megaslide, as proposed by 
Walker and Massingill (1970) on the basis of seismic evidence, or a series of large (10-15 m thick) slide blocks of perhaps more local origin.

\section{Facies Distribution and Sequences}

The percentages of different sedimentary facies present in the recovered section at each site are shown in Table 1. The biogenic facies are of minor importance volumetrically, occurring only as a thin surface veneer over the fan and near the base of the deepest hole (Hole 615). The fine-grained terrigenous facies are everywhere dominant. Silt-laminated muds are most abundant close to the channel on both the middle and lower fan, and also at Site 616 where they probably represent overbank deposits adjacent to a former buried channel. The clay and mud facies is more abundant both away from the channel and as thick channel fill deposits. The coarser-grained silt and sand facies are most abundant at the lower fan lobe sites and, to a lesser extent, near the base of the sand facies in the midfan channel sites. In both cases, analysis of wireline logs suggests that core recovery was more complete in the fine-grained facies so that actual percentages of sands and silts are relatively higher than recorded from cores and might be as much as $60-70 \%$ on the lobes and $20 \%$ in the channels (Coleman, Constans et al., this volume). Pebbly muds and gravels are a very minor facies recovered only in the channels.

The vertical sequences in which the various facies occur are described in more detail in the site chapters (this volume) and in the introductory chapter (this volume). We simply note here that, although clear trends of grain size and bed thickness are observed, vertical sequences are rather more variable than those classically related to fan deposits (Walker, 1978; Stow, 1985). In particular: (1) the lower fan lobe sites show coarsening-upward, fining-upward, blocky, and irregular sequences over tens of meters of section; (2) the midfan channel sites show somewhat irregular fining-upward sequences and a monotonous mud fill, and (3) the midfan levee and overbank sites show coarsening-upward, fining-upward, and symmetrical sequences. Smaller scale sequences over 2 to $10 \mathrm{~m}$ of section in the lower fan lobe sites might be considered similar in origin to the compensation cycles described by Mutti and Sonnino (1981), although coarsening, fining, and symmetrical sequences are all present.

\section{Sediment Source and Supply}

The sediment composition and grain size clearly reflects dominant supply from the Mississippi River and Delta systems (Davies, 1972; Devine et al., 1973). This is in agreement with the general fan setting and morphoseismic evidence. The material supplied is mainly fine grained, texturally mature but compositionally less mature and with common terrigenous organic material.

The very large volumes of sediment supplied to the shelf and upper slope has led to major instability, diapiric activity, and rapid resedimentation downslope. The most active fan growth has been during periods of lowered sea level, when large muddy turbidity currents built upon the channel levees, sand, and gravel from the shelf edge was very effectively funnelled far offshore to the lower fan terminal lobes, and an elongate fan shape was developed. The late glacial and postglacial sea-level rise resulted in relatively less sand input and rapid channel plugging by muds and clays.

The high sea-level stand during the Holocene has rendered much of the fan relatively inactive with only slow accumulation of pelagic biogenic sediments. A similar system probably prevailed during earlier interstadial and interglacial periods, as evidenced by the biogenic ooze recovered at the base of the deepest hole. However, a large part of this ooze was apparently resedimented downslope from the continental shelf off Florida.

\section{ACKNOWLEDGMENTS}

T. Barrett and J. Schoonmaker reviewed an earlier draft of this manuscript.

\section{REFERENCES}

Arthur, M. A., 1979, Origin of Upper Cretaceous multicolored claystones of the Western Atlantic. In Tucholke, B. E., Vogt, P. R., et al., Init. Repts. DSDP, 43: Washington (U.S. Govt. Printing Office), $417-420$.

Bouma, A. H., 1962. Sedimentology of Some Flysch Deposits: Amsterdam (Elsevier).

1969. Methods for the Study of Sedimentary Structures: New York (Wiley-Interscience).

Carver, R. E., 1971. Procedures in Sedimentary Petrology: New York (Wiley-Interscience).

Davies, D. K., 1972. Deep sea sediments and their sedimentation, Gulf of Mexico. Am. Assoc. Pet. Geol. Bull., 56(11):2212-2239.

Dean, W. E., Leinen, M., and Stow, D. A. V., 1985. Classification of deep-sea fine-grained sediments. J. Sediment. Petrol., 55:250-256.

Dean, W. E., and Parduhn, N. L., 1984. Inorganic geochemistry of sediments and rocks recovered from the southern Angola Basin and adjacent Walvis Ridge, Sites 530 and 532, DSDP Leg 75. In Hay, W. W., Sibuet, J.-C., et al., Init. Repts. DSDP, 75: Washington (U.S. Govt. Printing Office), 923-958.

Devine, S. B., Ferrell, R. E., Jr., and Billings, G. K., 1973. Mineral distribution patterns, deep Gulf of Mexico. Am. Assoc. Pet. Geol. Bull., 57(1):28-41.

Mutti, E., and Sonnino, M., 1981. Compensation cycles: a diagnostic feature of turbidite sandstone lobes. Int. Assoc. Sedimentologists, 2nd European Reg. Mtg. Bologna, Abstracts, pp. 120-123.

Müller, G., and Gastner, M., 1971. The "Karbonate Bombe," a simple device for the determination of the carbonate content in sediments, soils, and other materials. Neues. Jahrb. Mineral. Monatsh., 10: 466-469.

Piper, D. J. W., 1978. Turbidite muds and silts on deep-sea fans and abyssal plains. In Stanley, D. J., and Kelling, G. (Eds.), Sedimentation in Submarine Canyons, Fans and Trenches. Stroudsburg, PA (Dowden, Hutchinson and Ross), pp. 163-176.

Stanley, D. J., 1981. Unifites: Structureless muds of gravity-flow origin in Mediterranean basins. Geo-Mar. Lett., 1:77-84.

Stow, D. A. V., 1985. Deep-sea clastics: where are we and where are we going? In Brenchley, P. J., and Williams, B. P. J. (Eds.), Sedimentology: Recent Developments and Applied Aspects. Geol. Soc. London Spec. Publ., 18:67-94.

Stow, D. A. V., and Piper, D. J. W., 1984. Deep-water fine-grained sediments: facies models. In Stow, D. A. V., and Piper, D. J. W. (Eds.), Fine-Grained Sediments: Deep-Water Processes and Facies. Geol. Soc. London Spec. Publ., 15:611-645.

Stow, D. A. V., and Shanmugam, G., 1980. Sequence of structures in fine-grained turbidites: comparison of recent deep-sea and ancient flysch sediments. Sediment. Geol., 25:23-42.

Stow, D. A. V., Cremer, M., Droz, L., Normark, W. R., O'Connell, S., et al., 1985. Mississippi Fan sediments: facies, composition and texture. In Bouma, A. H., Normark, W. R. and Barnes, N. E. (Eds.), Deep-Sea Fans and Related Turbidite Systems: New York (Springer-Verlag), pp. 259-266.

Walker, J. R., and Massinghill, J. V., 1970. Slump features on the Mississippi Fan, NE Gulf of Mexico. Geol. Soc. Am. Bull., 81:31013108. 
Walker, R. G., 1978. Deep water sandstone facies and ancient submarine fans: models for exploration for stratigraphic traps. Am. Assoc. Pet. Geol. Bull., 62:932-966.

Walsh, J. N., and Howie, R. A., 1980. An evaluation of the performance of an inductively coupled plasma source spectrometer for the determination of the major and trace element constituents of silicate rocks and minerals. Mineral. Mag., 43:967-974.

Date of Initial Receipt: 11 March 1985

Date of Acceptance: 30 June 1985
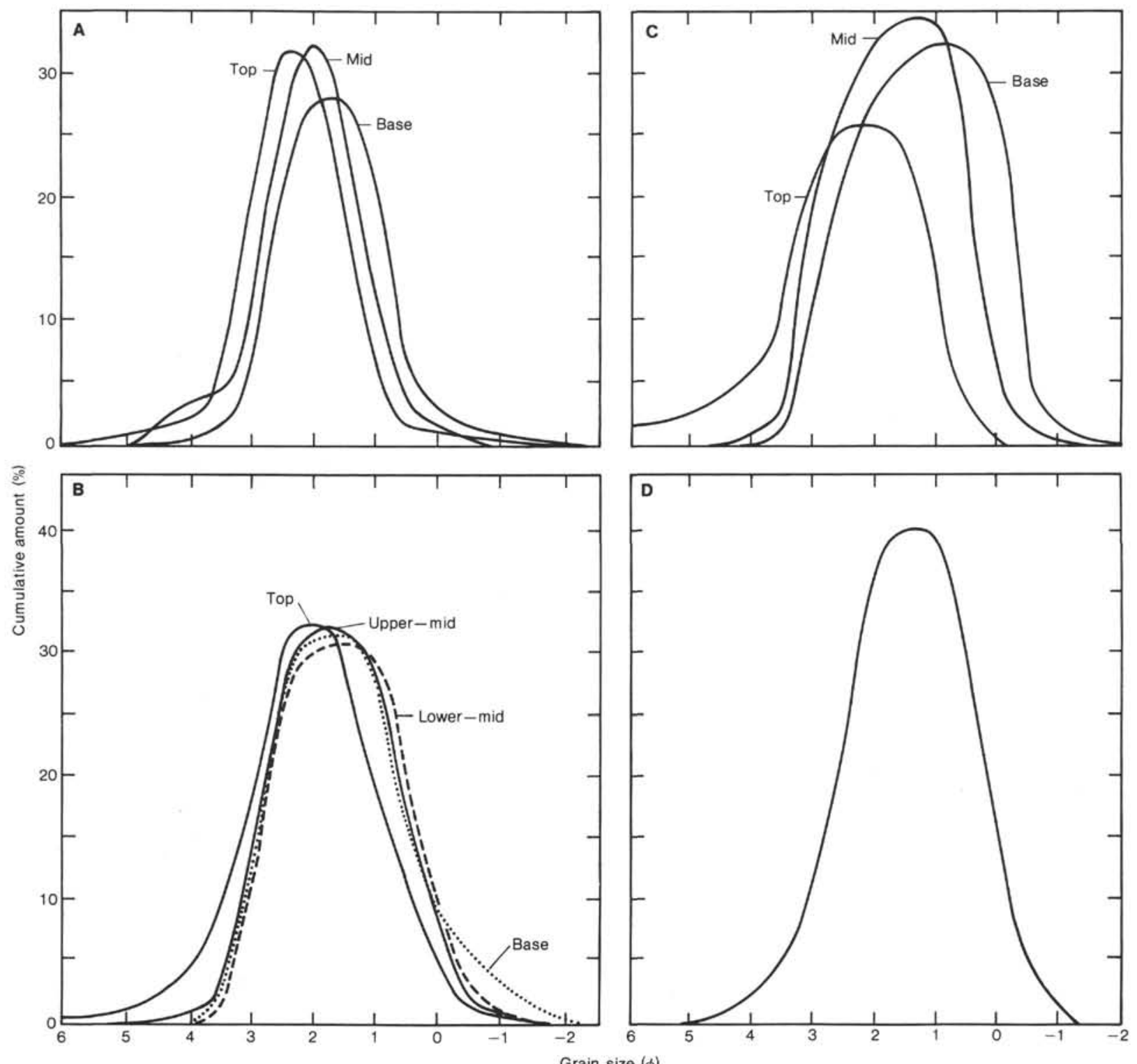

Figure 9. Smoothed frequency histograms for selected grain size plots of Mississippi Fan sediments. (A, B) Thick graded sand, Site 614; (C) thick graded sand, Site 615; (D) graded sand over gravel, Site 621; (E) silt-laminated muds and clays and muds, Sites 614 and 615; (F) clays and muds, Site 616; (G) silt-laminated muds and clays and muds, Site 617; (H) silt-laminated muds and clays and muds, Site 620; (I) clays and muds, Site 621; (J) ooze and muddy ooze, Site 615; (K) muddy silts (and muddy sands), Sites 615 and 621. 
FACIES, COMPOSITION, AND TEXTURE OF SEDIMENTS
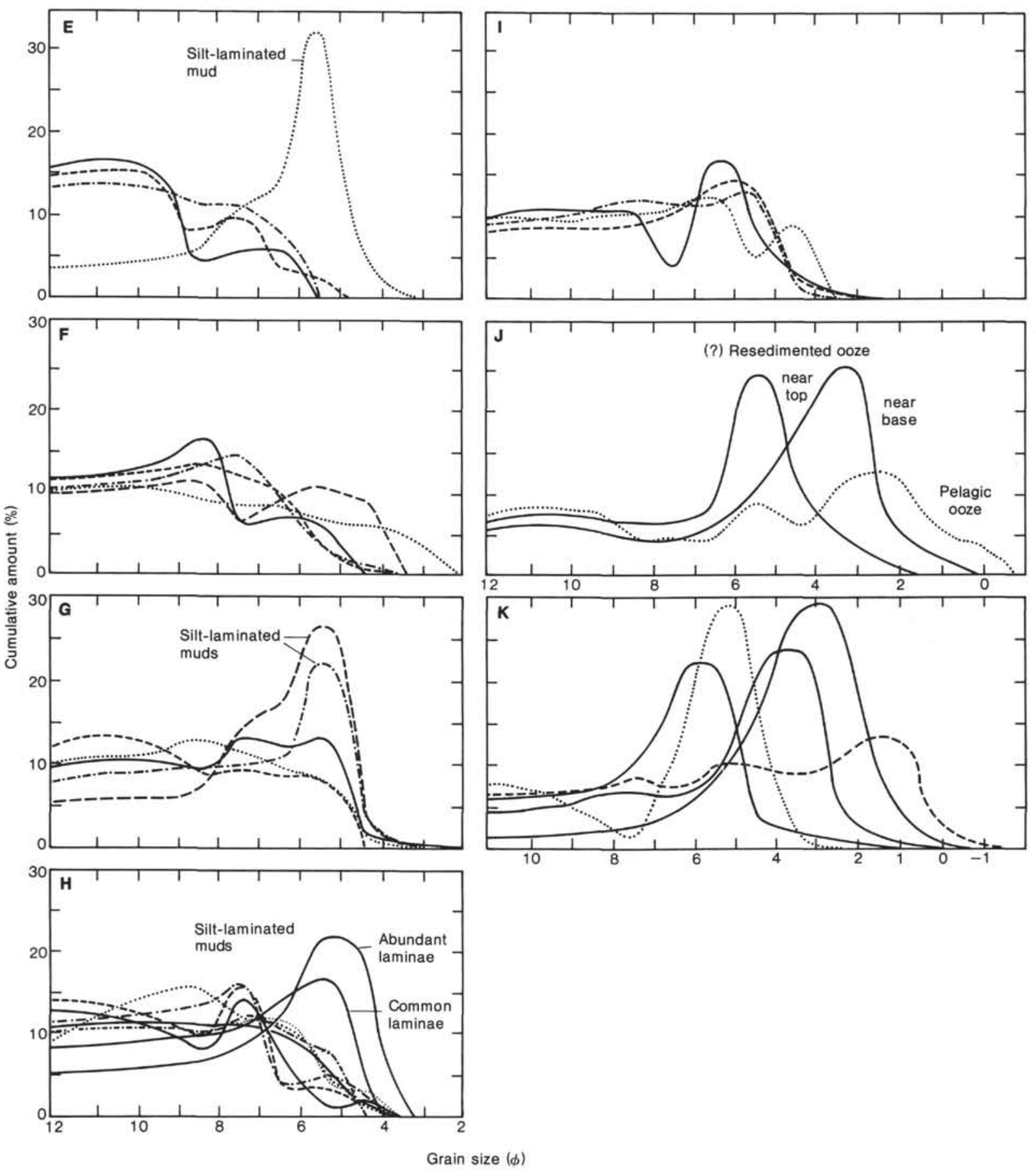

Figure 9 (continued). 